\title{
The American Historical Association: Latin American Labor History
}

\author{
Fred Murphy \\ New School for Social Research
}

Several of the panels on Latin America at the December 1990 meeting of the American Historical Association took up themes and debates of concern to historians of labor and the working class. In a panel entitled "Immigrants, Not Conquistadors: The Spanish Presence in Latin America during the National Period," Diana Velez (Tinker Foundation) stressed the way shifts in Spanish government policy affected the ebb and flow of emigration toward Latin America in the pre-World War I period. While nineteenth-century governments had sought to bar or tightly restrict emigration out of national security concerns, a looser policy was adopted as officials came to perceive that permitting and regulating emigration could offer an alternative to agrarian reform, a means of widening foreign markets for Spanish exports, and a source of foreign currency income from Spaniards working abroad and sending a portion of their wages home. Birgit Sonnesson (New York University) compared Spanish chain-migration to Puerto Rico and Cuba, stressing the effects of the different social formations in the Spanish provinces where emigrants originated. José Moya (University of California, Los Angeles) examined Spanish immigrants in Argentina between 1855 and 1930. Evidence from census manuscripts cast doubt on the standard two-class model of nineteenth-century Argentina, showing both an expansion of the middle class due to increasing public employment and a slow, incomplete process of proletarianization as industrial employment grew but mechanization lagged. Argentina attracted large numbers of skilled immigrants, and the labor force did not undergo deskilling in the early phases of industrialization. Indeed, the proportion of skilled workers in the labor force grew from 34 percent in 1870 to 43 percent in 1914.

A panel on "Recent Research on the History of the Family in Latin America" included a paper by Mark Szuchman (Florida International University) that called for further research on changes in productive relations and the impact thereof on the proletarian family. He suggested that the Latin American experience contrasted with that of Western Europe. Whereas capitalist development weakened the patriarchal family in Europe, in Latin America it worsened the position of women by driving them back into the home. Elizabeth Ann Kuznesof (University of Kansas) pointed out that recent research on family history in Brazil has highlighted the prevalence there of nuclear and female-headed households in urban areas and among ex-slaves, thereby challenging the paradigm developed by Gilberto Freyre wherein the patriarchal extended family was considered hegemonic. 
"Workers, Populism, and the Latin American State, 1917-1948" was the topic of a panel featuring papers on Mexico, Peru, and Argentina. Each exemplified what commentator Barbara Weinstein (SUNY, Stony Brook) welcomed as a "revisionist view of populism" wherein preoccupation with the co-optation or repression of workers by the state is giving way to a more nuanced understanding of how workers and labor movements act autonomously and pursue their own interests even while participating in multiclass political movements or accepting state support. Thus David LaFrance (Oregon State University) discussed how textile workers in Puebla, Mexico, in the 1910s gained leverage against provincial officials by appealing to federal authorities; Steven Hirsch (Ohio University) portrayed Peruvian textile unionists in the 1940s defying the populist APRA to engage in strikes and confrontations with employers; and David Greenberg (Pace University) reinterpreted Argentine labor history of the $1930 \mathrm{~s}$ to stress how telephone workers organized effectively well before Juan Domingo Perón's rise to political power and the consolidation of the Peronist labor movement. Weinstein concluded her comments on these papers by suggesting that, in light of the current "crisis of socialism," it behooves historians to reconsider Latin American populism "not as a barrier to 'true socialist revolution' but as a political agenda that, in certain circumstances, has recognized workers' rights and centrality to national development, and used the state as a mechanism for redistribution of income and services."

"Gender and Popular Resistance Movements" was the topic of a panel that included papers on Brazil by Joel Wolfe (Williams College), on Guatemala by Deborah Levenson (Columbia University), and on Argentina by Daniel James (Yale University). Wolfe cited massive female participation in the 1953 "strike of 300,000 " in São Paulo to challenge the customary view of women workers as passive and lacking in militancy. In this instance, female textile workers were more disposed than were male metalworkers to confront the police and to remain on strike until all demands were won. In contrast, Levenson found in Guatemala widespread acceptance by women workers of traditional gender roles. For Guatemalan women to be active union militants they must embark deliberately on personal journeys away from conventional roles as mothers and homemakers: "Women are more likely to become self-conscious as they become class-conscious." James's account of his extensive oral-history interviews with Doña María, a longtime Peronist militant in the Argentine meatpacking industry, stressed the nature of such accounts as constructed narratives that require symptomatic readings. While gender was not immediately apparent in Doña María's storylargely recounted in class terms - James nonetheless teased out two rival sets of gender images: on the one hand, acceptance of female stereotypes corresponding to Peronist ideology ("the home is the image of the nation . . ."); on the other, rebelliousness and a self-image as "a daring woman." Comments by Michael Jiménez (Princeton University) proposed a research agenda for further work that could clarify how the political economy of dependent capitalism relied on gender 
inequalities, how this in turn reinforced and transformed gender ideologies, and how diverse kinds of oppositional activity were informed by gender.

\title{
United Mine Workers of America: Centennial Conference
}

\author{
Daniel Letwin \\ Pennsylvania State University
}

The coal fields have been the setting for some of the most legendary traditions of class conflict in American labor history. Dishonest and irregular pay, child and convict labor, mine disasters and black lung, repression of unions and the suffocating paternalism of the company towns - these have been among the more potent symbols of labor exploitation in industrial America. Relatedly, the mining regions have yielded an unmatched legacy of labor militancy and solidarity, embodied most enduringly in the United Mine Workers of America (UMWA). The recent, hard-fought Pittston strike illustrates how alive and immediate this history remains in the coal fields today. On October 18-20, 1990, approximately one hundred people, primarily labor historians and UMWA officials, gathered at Penn State University to mark the union's centenary and to evaluate its history and current prospects.

UMWA President Richard Trumka set the tone with his keynote address, "A World to Win: A New Unionism for the '90s." In order to remain vital, he argued, the labor movement needs to redefine the meaning of unionism, to expand beyond the workplace to confront the community needs - social, financial, legal, etc. - of its members as well. But in doing so, he added, the unions must not shed their traditional commitments to workplace issues and social justice and become mere purveyors of credit cards and travel services. It is both a moral and a strategic imperative that the unions reconcile their roles at the workplace and in the community, for working people pursue empowerment in both realms. Trumka turned next to the "new proletariat of service workers" in offices, hospitals, and the like. He called on the labor movement to reject the assumption that these workers cannot be organized, likening such thinking to that of the American Federation of Labor leaders regarding industrial workers during the 1930s. Finally, Trumka noted the response of white working people in Louisiana to the racist populism of U.S. Senate candidate David Duke. Liberals, he observed, tend to denounce the racism and move on; the challenge of the labor movement is to address the economic distress and political disaffection that make struggling white workers susceptible to Duke's demogoguery. "Labor is the only entity in America capable of challenging American racism at its roots," Trumka concluded. 